\title{
ENVIRONMENT OF FOOD MARKET \\ OF SCHOOL-AGE CHILDREN
}

\section{ЗОВНІШНС СЕРЕДОВИЩЕ РИНКУ ПРОДУКТІВ ТА ПОСЛУГ ХАРЧУВАННЯ ДІТЕЙ ШКІЛЬНОГО ВІКУ}

\section{Anastasiia Konovalenko ${ }^{1}$}

DOI: https://doi.org/10.30525/978-9934-588-38-9-29

\begin{abstract}
The article is devoted to the results of the study of the influence of external factors on the trends of the market of products and catering services for school-age children in Ukraine in order to identify existing opportunities for business development in this market and to assess possible threats.
\end{abstract}

The subject of the study - factors of macro- and microenvironment of the market of products and catering for school-age children.

The methodology of the study involves the implementation of PECST-analysis (which is a modification of the PEST analysis method) using the method of expert assessments in determining the impact of external factors and their relation to market opportunities and threats. The significance of the subgroups of macro-environment and microenvironmental factors is estimated based on a multicriteria approach. When choosing alternatives to solve the market problem, the methodology of $\mathrm{ABC}$ analysis was used.

Purpose and conclusion of the study. The results of scientific researches show that despite the efforts of the authorities in Ukraine, for a long time the actual nutrition of the infant population of Ukraine is characterized by the deterioration of the structure of the product set, the imbalance of the diets of children in the content of proteins, fats, carbohydrates, vitamins, minerals. The formation of healthy lifestyles among children and young people in Ukraine is an urgent problem that needs a systemic solution.

The purpose of the study is to evaluate the impact of environmental factors on the development of the market for food and food for school-age children to select alternative solutions to the problem of improving the nutrition

\footnotetext{
${ }^{1}$ Candidate of Economic Sciences,

Associate Professor at the Department of Marketing,

Dmytro Motormyi Tavria State Agrotechnological University, Ukraine
} 
of students. Political-legal, economic, cultural-ethical, socio-demographic and technological factors are among the factors of the macro-environment of the market. Most Ukrainian schoolchildren need to eat outside of their residence during the school week. The problem of organizing the nutrition of children in an organized group becomes more urgent. The school cafeteria is considered in the article as one of the alternative options for children to get hot meals throughout the day for such manifestations as the level of nutrition and quality of service.

Microenvironmental factors include consumers, competitors, suppliers and contact audiences. Expert evaluation of these trends was made, taking into account the significance of subgroups of factors. It was concluded that cultural, ethical and technological factors of the macro environment, as well as consumers and competitors as factors of microenvironment, are the most influential on the market development opportunities. The results of the study indicate alternative ways of minimizing the negative impact of existing threats on the market and exploiting existing opportunities. The set of alternative directions, which are the most effective for achieving the greatest shifts in the further development of the market of products and services of nutrition of school-age children is determined.

\section{1. Ветуп}

Відповідно до Глобального плану дій з профілактики і контролю неінфекційних захворювань на 2013-2020 рр., країнам-членам Всесвітньої організації охорони здоров'я (ВОО3) наполегливо рекомендується поширювати здорове харчування серед населення з метою скорочення передчасної смертності, зупинки зростання поширеності ожиріння та діабету, обмеження споживання солі, цукру, насичених жирів та трансжирів. Доведено, що саме здорове харчування дітей та підлітків $є$ важливою передумовою зниження ризику серцево-судинних захворювань, діабету та раку як у дитячому, так і дорослому житті [1].

Формування здорового способу життя серед дітей та молоді в Україні є актуальною проблемою, що потребує системного вирішення. Досі відсутня єдина стратегія забезпечення комплексних заходів щодо регулювання стану здоров'я дітей та молоді та сприяння формування здорового способу життя. За роки незалежності було ініційовано низку державних програм та концепцій, які передбачали сприяння зміцненню здоров'я дітей 
та молоді, а саме: Концепція формування позитивної мотивації на здоровий спосіб життя у дітей та молоді (2004р.); Міжгалузева комплексна програма «Здоров’я нації» на 2002-2011 роки; Концепція Загальнодержавної цільової соціальної програми «Здорова нація» на 2009-2013 роки; Державна програма «Репродуктивне здоров’я нації на період до 2015 року»; Стратегія демографічного розвитку на період до 2015 року; Концепція загальнодержавної цільової соціальної програми «Формування здорового способу життя молоді України» на 2013-2017 роки.

Однак, не дивлячись на зусилля влади, результати низки проведених наукових досліджень свідчать про те, що протягом тривалого часу фактичне харчування дитячого населення України характеризується погіршенням структури продуктового набору, розбалансованістю харчових раціонів дітей за вмістом білків, жирів, вуглеводів, вітамінів, мінеральних речовин (Корзун В.Н., 1990-2009, Кульчицька В.П. та співавт., 1997- 2004; Сердюк А.М. та співав., 2003; Федоренко В.І., 2007; Гуліч М.П., 2009). Результатом таких процесів є погіршення здоров'я дітей, яке проявляється у вигляді призупинення процесів акселерації та початком «децелірації» фізичного розвитку дітей на пострадянському просторі, в Україні у тому числі. Спостерігається процес астенізації серед міських дітей дошкільного та шкільного віку (Сухарев А.Г., 2004; Полька Н.С. та співав., 2000-2009; Неділько В.П., 2007-2009; Соколов А.Я., 2009). В структурі загальної захворюваності дітей перше місце посідають хвороби органів дихання, друге - органів травлення, третє - ендокринної системи, розлади харчування та порушення обміну речовин [2].

Основою розробки стратегії підвищення безпеки харчування дітей шкільного віку мають стати результати наукових досліджень, які окреслюють сучасний стан ринку продовольства для дітей, а також існуючі тенденції, які формують можливості розвитку ринку або обумовлюють виникнення загроз.

Метою дослідження є визначення альтернативних напрямів вирішення існуючих проблем розвитку ринку продуктів та послуг харчування дітей шкільного віку та використання існуючих можливостей на основі оцінки стану та тенденцій зовнішнього оточення ринку.

Завдання дослідження полягають в узагальненні чинників макро- та мікрооточення ринку, здійснення їх попередньої оцінки, вибір альтернативних варіантів подолання визначених загроз та використання можливостей. 


\section{2. Чинники макросередовища ринку}

Методичну основу здійснення дослідження впливу чинників макросередовища складають здобутки зарубіжних та вітчизняних науковців. Вагомий внесок у теорію та методологію проведення маркетингових досліджень зробили українські вчені, які сформували теоретико-методологічні основи здійснення маркетингових досліджень, визначили систему маркетингових досліджень, обгрунтували принципи та механізм їх проведення. Так, Зозульова О.В. у своїх роботах обгрунтовує методологію маркетингових досліджень інноваційних товарів. В роботах Ілляшенко С.М. висвітлені теоретико-прикладні аспекти процедурі проведення маркетингових досліджень в Інтернеті. Методи маркетингових досліджень ціни стали предметом вивчення Окландера М.А. та Чукурної О.П.. Теоретико-методологічний інструментарій системи маркетингових досліджень інновацій висвітлені у роботах Яшкіної О.І.. Методика проведення маркетингових досліджень на національних та міжнародних ринках розкрита у роботах Старостіної А.О.

Ринок продуктів та послуг харчування для дітей характеризується впливом факторів мікро- та макромаркетингового середовища. Мінливість стану зовнішнього середовища обумовлює необхідність адаптувати обрану підприємствами (організаціями) стратегію відповідно до змін, що відбуваються у макро- та мікрооточенні. Взаємодія суб'єктів господарювання із макромаркетинговим середовищем ускладнена тим, що ринкові структури не мають важелів впливу на чинники макросередовища, а можуть лише підлаштовувати власну діяльність під його стан. До макромаркетингового середовища відносять такі групи чинників: демографічні, економічні, природно-екологічні фактори, науково-технічні, політико-правові та соціально-культурні [3, с. 199].

3 метою дослідження характеру впливу чинників макромаркетингового оточення ринку послуг з харчування для дітей шкільного віку слід визначити ключові чинники, які здійснюють вплив на зміну споживчої поведінки дітей та підлітків при прийнятті рішення про придбання та споживання продуктів харчування, а також впливають на вибір стратегії підприємствами на ринку продуктів харчування для дітей, на основі PEST-аналізу.

Здійснення PEST-аналізу дозволяє оцінити ключові тенденції певного ринку, його результати формують основу для визначення переліку загроз та можливостей при здійсненні SWOT-аналізу. PEST-ана- 
ліз $є$ інструментом довгострокового стратегічного планування та його результати можуть використовуватись протягом 3-5 років за умови щорічного оновлення даних. PEST-аналіз передбачає стратегічний аналіз чотирьох елементів, але функціонування того чи іншого ринку під впливом зовнішнього середовища залежить від власного набору ключових факторів, який найбільш впливає на даний ринок [4, с. 42].

Враховуючи специфіку ринку продуктів та послуг харчування дітей, $з$ метою точнішого аналізу чинників макромаркетингового оточення доречно застосувати модифікований варіант PEST-аналізу, а саме аналіз PECST (PEST + Cultural-ethical), який передбачає додаткову оцінку культурно-етичних чинників, які впливають на стан ринку. Таким чином, PECST-аналіз впливу чинників макромаркетингового середовища (рис. 1) ринку послуг харчування для дітей шкільного віку передбачає аналіз наступних груп чинників:

- Political (політико-правові);

- Economical (економічні);

- Cultural-ethical (культурно-етичні);

- Social (соціально-демографічні);

- Technological (технологічні).

Дослідження сучасного стану та існуючих тенденцій розвитку ринку продуктів та послуг харчування для дітей дозволило визначити чинники макромаркетингового середовища політико-правового, еко-

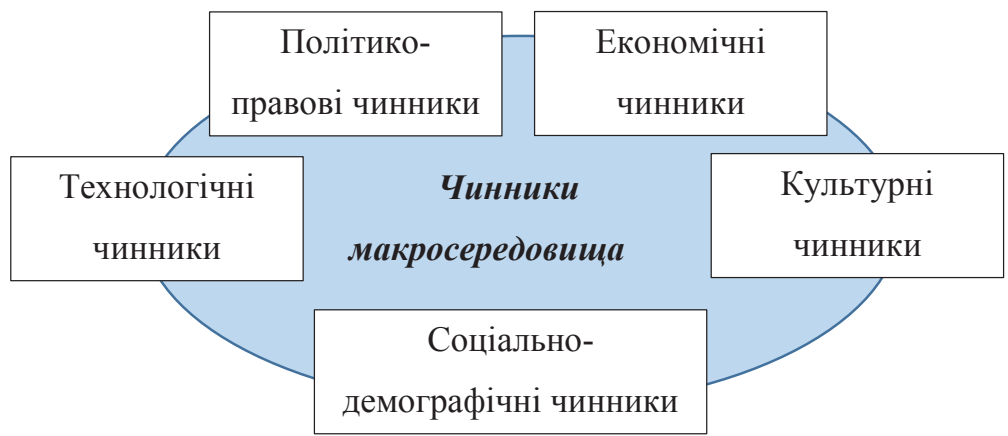

Рис. 1. Чинники макросередовища ринку продуктів та послуг харчування дітей

Джерело: укладено автором 
номічного, культурного, соціально-демографічного та технологічного характеру. Зазначені чинники можуть прямо або опосередковано впливати на стан ринку продуктів та послуг харчування дітей шкільного віку в Україні. Оцінка сили та характеру їх впливу дозволить отримати інформаційну базу для визначення змістовного наповнення маркетингового механізму управління безпекою харчування дітей:

- визначити існуючі можливості розвитку маркетингової діяльності суб'єктів господарювання на ринку продуктів та послуг харчування дітей шкільного віку;

- окреслити детермінанти, які спричиняють виникнення загроз, як розвитку ринку продуктів та послуг харчування дітей шкільного віку, так й загальному рівню безпеки харчування школярів;

- сформувати пріоритетні завдання досягнення максимально можливого за існуючих умов рівня безпеки харчування дітей шкільного віку [5].

Проведений аналіз політико-правових чинників макромаркетингового середовища ринку продуктів та послуг харчування для дітей шкільного віку [6] дозволяє зробити висновки, що в Україні сформовано законодавчу базу, яка регулює питання організації дитячого харчування та контролю його якості. Однак, існують й певні проблеми державного регулювання питань продовольчої безпеки у дитячому сегменті, спричинені недосконалістю чинного законодавства, невідповідністю окремих норм поточним умовам економічної діяльності суб'єктів ринку, проблемам, викликаним значним рівнем корумпованості у сфері державних закупівель тощо. Окремі положення є застарілими та потребують перегляду й адаптації до вимог сьогодення. Поведінка суб'єктів на ринку продуктів та послуг харчування для дітей також трансформується від впливом активізації евроінтеграційних процесів, внутрішньополітичних процесів та проявів зовнішньої політики держави

Визначено ключові економічні чинники макромаркетингового середовища ринку [7]. Одним з найважливіших показників стану економіки держави $є$ валовий внутрішній продукт (ВВП) на душу населення. Експерти прогнозують зростання ВВП України у найближчі 5 років на $33 \%$, підвищення рівня безробіття до 9,2\% наприкінці 2019 р. Спостерігаються позитивні зрушення, що обумовлені реформами у системі правосуддя, правоохоронних органах та антикорупційних структурах. Заважають економічним перетворенням високий 
рівень втручання з боку правоохоронних та антикорупційних органів, політична турбулентність, обмежену дієздатність влади та високі ризики дестабілізації ситуації. Водночас, фахівці прогнозують стабілізацію розвитку економіки України з 2021 р.

Спостерігається зниження рівня життя населення в Україні під впливом падіння курсу гривні, зростання цін, інфляції; посилення податкового тиску на доходи населення; наявність заборгованості по виплатам заробітної плати; - низький рівень основних державних соціальних гарантій; зростання тарифів на житлово-комунальні послуги та енергоносії тощо. Виробники продуктів харчування для дітей відчувають серйозне зниження купівельної спроможності населення, яке, здебільшого, викликано зростанням тиску комунальних тарифів, падінням курсу гривні.

За результатами дослідження визначено, що у структурі ресурсів домогосподарств переважають доходи у вигляді оплати праці, знижується підприємницька активність населення та доходи, пов'язані з цим, зменшується частка соціальної допомоги населенню у сукупному розмірі ресурсів домогосподарств. Прожитковий мінімум постійно підвищували, однак продовольчий кошик на 2019 рік потребує перегляду. Темпи зростання законодавчо встановленого рівня прожиткового мінімуму та мінімальної заробітної плати мають позитивну динаміку та корелюються між собою. Протягом 10 років відбувалось перевищення рівня забезпеченості прожиткового мінімуму мінімальною заробітною платою на рівні, вищому за 100\%, однак за європейськими стандартами мінімальна заробітна плата має складати більше 2,5 розміру прожиткового мінімуму.

До числа культурних чинників макромаркетингового середовища, які впливають на стан ринку продуктів та послуг харчування для дітей шкільного віку, віднесено наступні: важливим критерієм вибору батьками продуктів харчування для дітей $€$ їх висока якість; серед українців все більшої популярності набувають продукти вітчизняного та локального виробництва; з'являються та набувають популярності нові формати швидкого харчування; зростає частота харчування населення (у тому числі, дітей та підлітків) поза межами дому; набуває розповсюдження та популярності концепція здорового харчування, набуття корисних харчових звичок, дотримання принципів активного стилю життя; зростають 
вимоги споживачів до рівня та якості обслуговування, внутрішнього оздоблення закладів громадського харчування, зручності та екологічності упакування продуктів; споживачі все частіше прагнуть поєднувати прийом їжі із розвагами; спостерігається збільшення кількості людей, які свідомо відмовляються від споживання окремих категорій продуктів харчування за власними переконаннями.

За результатами проведеного аналізу визначено соціальнодемографічні чинники макромаркетингового середовища ринку продуктів та послуг харчування для дітей шкільного віку. До зазначених чинників віднесено поступове зменшення чисельності населення в Україні, зростання частки дітей шкільного віку у структурі наявного населення, погіршення стану здоров'я школярів, зростання кількості дітей, які потребують особливого раціону харчування, спричиненого станом здоров'я, підвищення соціальної активності жінок та загострення проблеми пошуку збалансованого поєднання ними суспільної активності із родиною.

Аналіз технологічних чинників [8] доводить, що запровадження технологічних інновацій в Україні сьогодні ускладнено браком власних обігових коштів підприємств харчової промисловості, обмеженістю державної підтримки та інвестування, що спричиняє низький рівень їх технічної оснащеності. На підприємствах знижуються обсяги запровадження досягнень науки та технологій, поглиблюється розрив між науковими установами та виробництвом.

За результатами аналізу сучасний тенденцій, визначено низку технологічних чинників макромаркетингового середовища ринку продуктів харчування для дітей шкільного віку. До їх числа віднесено застарілість технологій та рецептур виготовлення страв, матеріально-технічної та виробничо-технологічної бази підприємств, що забезпечують процес харчування дітей у закладах освіти. Шкільні їдальні здебільшого застарілі за будівельно-конструкторськими рішеннями, не мають привабливого зовнішнього вигляду. Модернізація та оновлення системи харчового сервісу у закладах середньої освіти ускладнено у зв'язку з браком коштів. До того ж оновленню шкільного харчового сервісу перешкоджає те, що персонал шкіл здебільшого працює за старими шаблонами, не прагне впроваджувати інновації, часто бракує кваліфікованого персоналу, здатного запроваджувати зміни у харчовому 
сервісі. Низький інноваційний потенціал провокує неспроможність запроваджувати нові технології та здійснювати високовитратні інноваційні зміни, однак, у той же час спостерігається активізація зусиль закладів громадського харчування запроваджувати технологічні інновації. Розвиток харчових технологій спричиняє збільшення частоти вживання дітьми рафінованих, синтезованих, надмірно оброблених термічно продуктів харчування із додаванням штучних хімічних домішок, замінників, підсилювачів смаку, барвників, ароматизаторів тощо.

\section{3. Оцінка впливу чинників макросередовища}

Проведення макросередовища ринку продуктів та послуг харчування для дітей передбачає виконання низки етапів, а саме:

1. Формулювання мети та задач дослідження. Постановка завдання для експертів.

2. Вибір методу проведення опитування.

3. Розробка матеріалів для проведення опитування, переліку питань.

4. Відбір експертів.

5. Проведення експертного опитування.

6. Аналіз результатів опитування [5].

Визначення маркетингових загроз та потенціальних можливостей розвитку ринку продуктів харчування для дітей передбачає здійснення відбору та експертної оцінки чинників макромаркетингового оточення. 3 метою здійснення аналізу факторів макромаркетингового середовища зазначені групи чинників систематизовано, здійснена їх попередня оцінка $з$ огляду на їх вплив на попит або пропозицію продуктів та послуг харчування для дітей шкільного віку, а також зазначена попередня оцінка відношення кожного з чинників до ринкових загроз або можливостей розвитку бізнесу.

За результатами опитування експертів отримано експертну оцінку чинників макромаркетингового середовища (табл. 1).

3 метою визначення важливості підгруп чинників використано метод критеріальної оцінки [9] чинників окремих груп чинників макромаркетингового середовища ринку продуктів харчування для дітей шкільного віку. Для оцінки значущості чинників використовується багатокритеріальний підхід. До системи критеріїв оцінки чинників макромаркетингового середовища віднесено кількість чинників у 


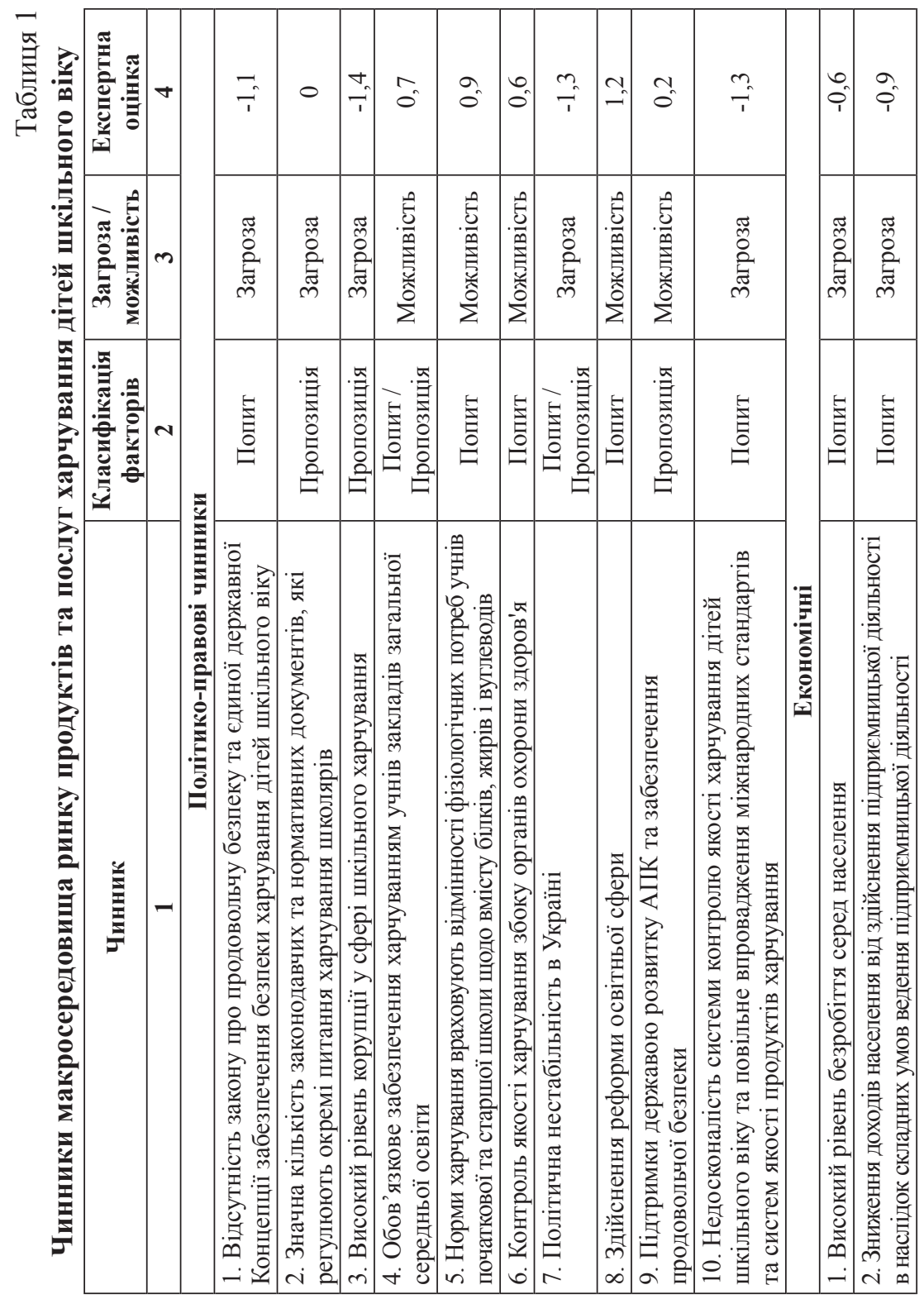


Anastasiia Konovalenko

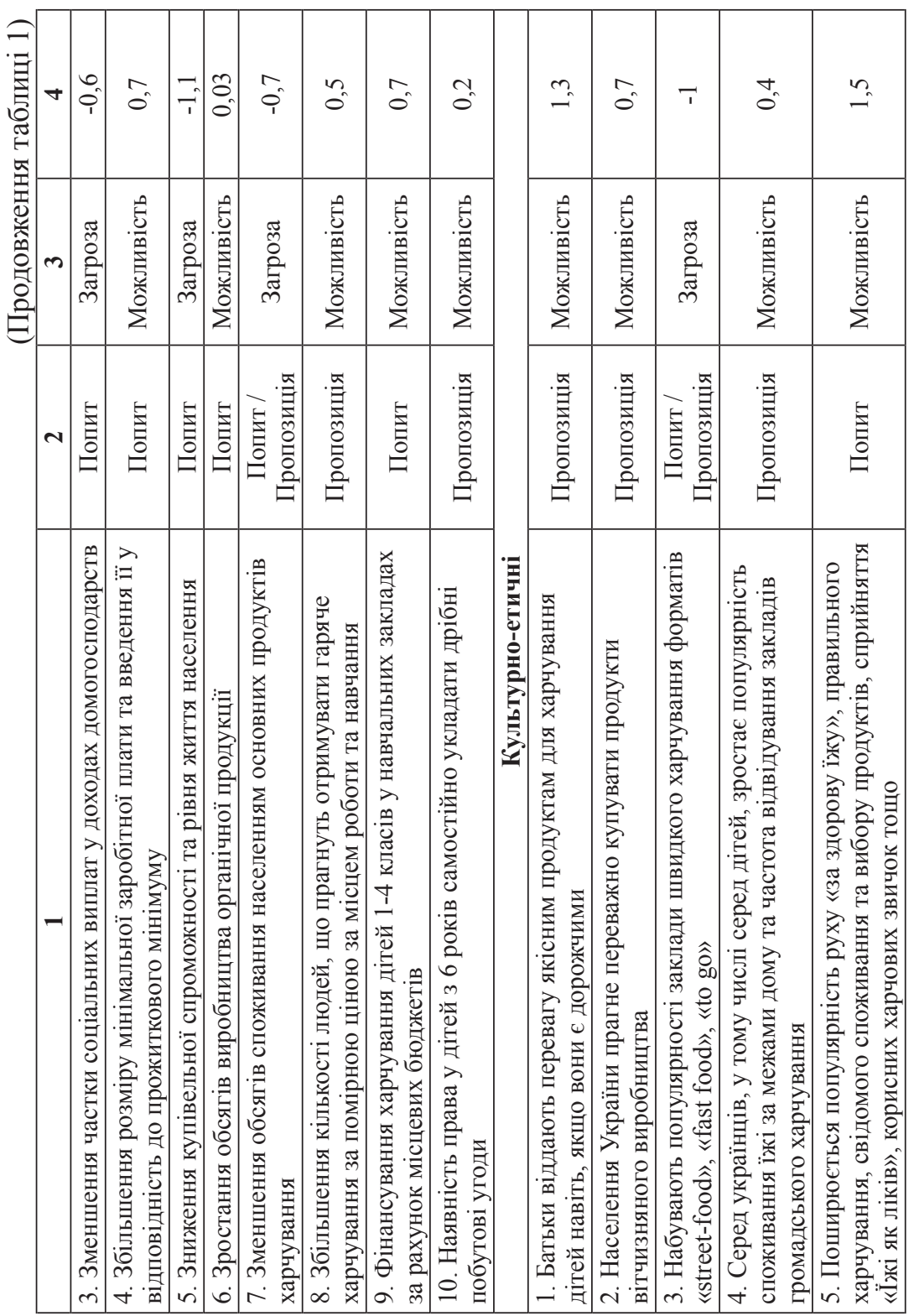




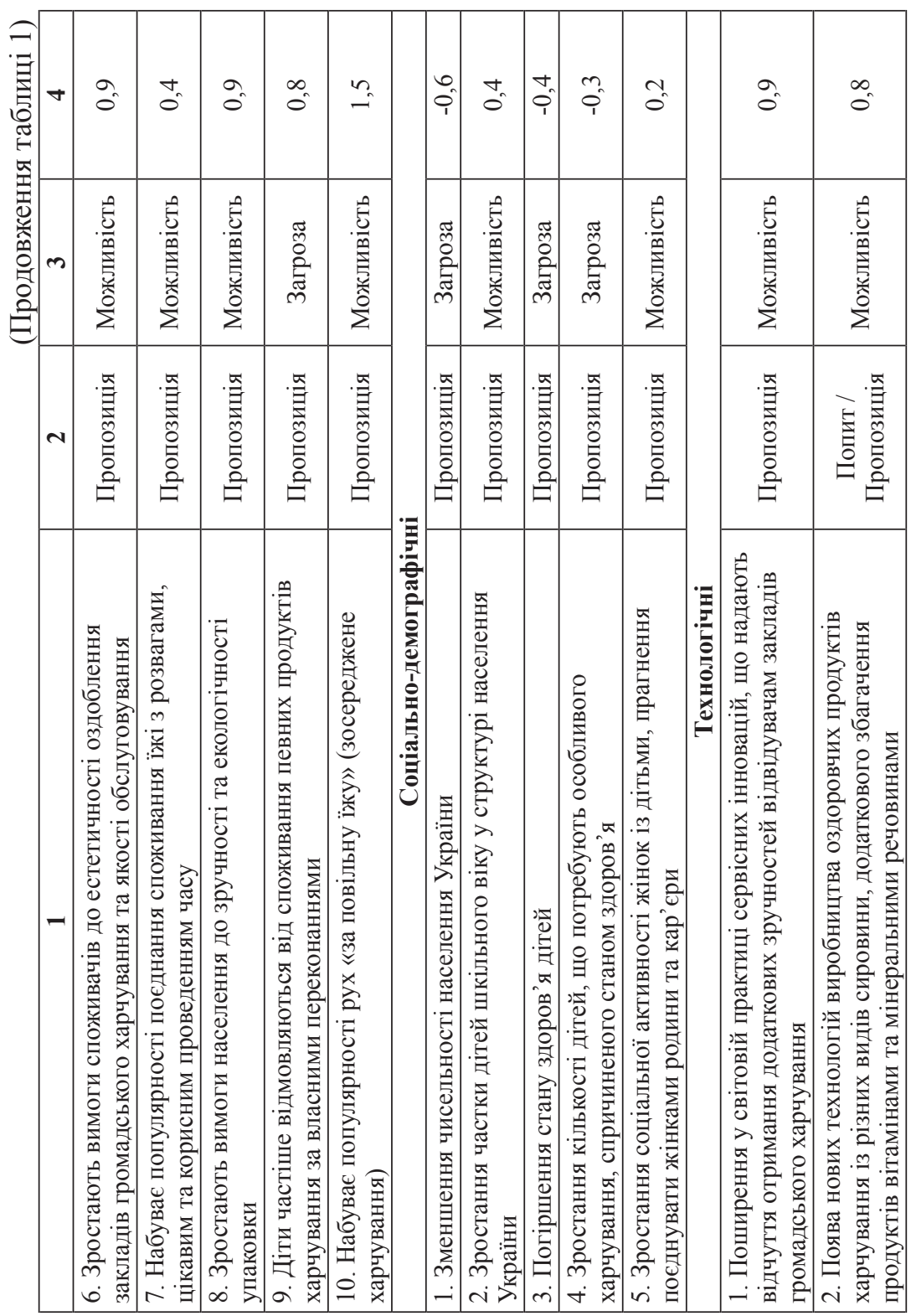




\section{Anastasiia Konovalenko}

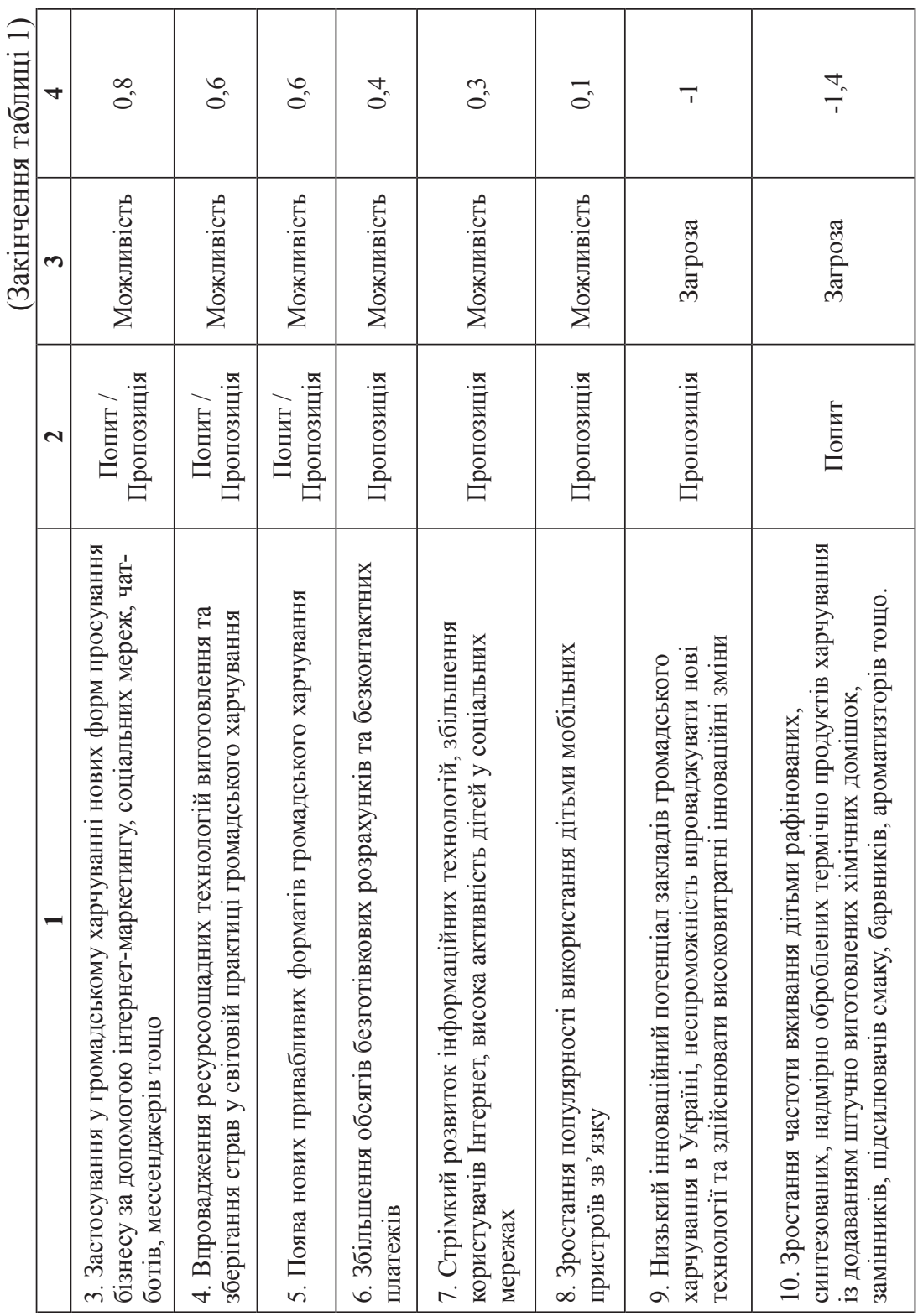


підгрупі; вагомість чинників у підгрупі; співвідношення між чинниками проблем і можливостей; співвідношення між чинниками попиту та пропозиції; складність подолання негативного впливу чинника чи використання можливостей; ймовірність посилення впливу чинника у майбутньому.

Оцінювання важливості кожного критерію здійснена групою експертів на основі попарного порівняння 3 іншими. У результаті сформовано півматрицю, у клітинах якої зазначено номери критеріїв, які оцінено як важливіші. Отримана кожним критерієм кількість переваг розрахована на основі кількості зазна-

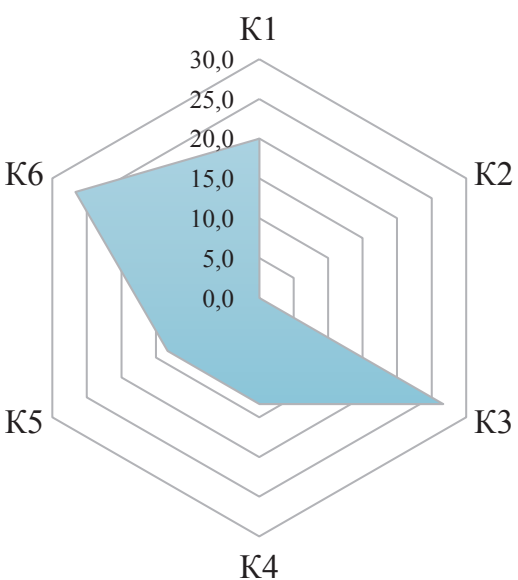

Рис. 2. Важливість критеріїв оцінки чинників зовнішнього оточення

Джерело: укладено автором чення кожного критерію у півматриці, що визначає «вагу» кожного з них. Важливість критеріїв оцінки чинників розподілена у відповідності до рисунку 2.

Найважливіше значення при оцінці чинників за підгрупами має значення співвідношення між факторами проблем та можливостей $\left(\mathrm{K}_{3}\right)$, а також ймовірність посилення впливу чинника у майбутньому $\left(K_{6}\right)$. Зазначені критерії $\epsilon$ найважливішими у попарному порівнянні 3 іншими, їх важливість складає 26,7\% від загальної суми переваг. Друге місце посів критерій оцінювання кількості факторів у підгрупі $\left(K_{1}\right)$, який отримав 3 переваги у попарному порівнянні та $20 \%$ загальної суми переваг. Третю позицію посіли критерії співвідношення між факторами попиту та пропозиції та складність подолання негативного впливу чинника $\left(K_{4}\right)$ чи використання можливостей, які він надає $\left(K_{5}\right)$. Зазначені критерії отримали по 2 переваги, їх важливість складає по $13,3 \%$. Критерій вагомості факторів у підгрупі $\left(\mathrm{K}_{4}\right)$ не отримав переваг у порівнянні із іншими чинниками, посів четверту позицію та оцінений як такий, важливість якого $є$ несуттєвою, тож даний критерій виключено й не буде враховано під час оцінювання факторів за під- 
Anastasiia Konovalenko

\begin{tabular}{|c|c|c|c|c|c|c|c|c|c|}
\hline \multirow{12}{*}{ 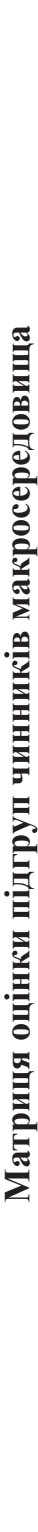 } & \multirow{10}{*}{ 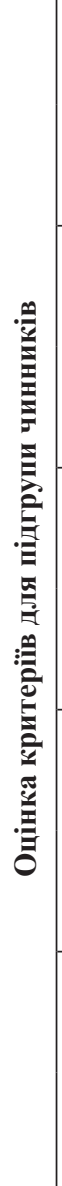 } & \multirow{2}{*}{ 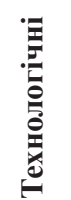 } & (У) внәжкяє & $\stackrel{\sigma}{\sigma}$ & กิ & ते & $\begin{array}{l}\text { i } \\
\text { i }\end{array}$ & $\begin{array}{l}\hat{b} \\
\text { i }\end{array}$ & $\begin{array}{l}\hat{\sigma} \\
0 \\
0\end{array}$ \\
\hline & & & $\begin{array}{c}\text { (9) } \\
\text { внцdәшәяЯ }\end{array}$ & $\begin{array}{l}n \\
n\end{array}$ & $n$ & $\infty$ & $n$ & $\stackrel{0}{0}$ & $\vec{f}$ \\
\hline & & \multirow{2}{*}{ 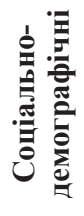 } & (У) внәжвяє & $\hat{\sigma}$ & $\hat{0}$ & $\stackrel{\infty}{+\infty}$ & $\begin{array}{l}\hat{6} \\
i\end{array}$ & ñ & $\begin{array}{l}\nabla_{n} \\
\text { n }\end{array}$ \\
\hline & & & $\begin{array}{c}\text { (9) } \\
\text { внцdәшэя }\end{array}$ & â & $\stackrel{0}{+}$ & $\stackrel{\infty}{\rightarrow}$ & $\stackrel{0}{0}$ & $\stackrel{0}{i}$ & $\stackrel{?}{2}$ \\
\hline & & \multirow{2}{*}{ 党: } & (У) внәжвяє & $\stackrel{m}{n}$ & $\stackrel{0}{6}$ & $\hat{n}$ & $\hat{n}$ & $\hat{n}$ & ñ \\
\hline & & & $\begin{array}{c}\text { (9) } \\
\text { внцdәшวу }\end{array}$ & in & $\hat{\sigma}^{\circ}$ & बे & 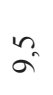 & $n$ & $\begin{array}{l}\text { ă } \\
\text { ñ }\end{array}$ \\
\hline & & \multirow{2}{*}{ 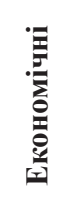 } & (У) внәжвяЕ & $\hat{0}$ & $\frac{m}{2}$ & ڤ్ & $\begin{array}{l}\infty \\
\infty \\
0\end{array}$ & $\hat{0}$ & $=$ \\
\hline & & & $\begin{array}{c}\text { (9) } \\
\text { внцdәшәя }\end{array}$ & $\underset{\forall}{\circ}$ & $\stackrel{0}{\infty}$ & $m$ & $m$ & $\stackrel{0}{+}$ & ๙ิ \\
\hline & & \multirow{2}{*}{ 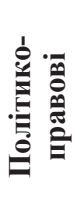 } & (У) внәжвяє & $\stackrel{8}{0}$ & $\frac{m}{2}$ & $\begin{array}{l}\hat{\sigma} \\
i\end{array}$ & $\begin{array}{l}\infty \\
\infty \\
0\end{array}$ & $\tilde{n}^{n}$ & $\stackrel{\infty}{n}$ \\
\hline & & & $\begin{array}{c}\text { (9) } \\
\text { внцdəшэя }\end{array}$ & $\hat{\sigma}^{\circ}$ & $\underset{\infty}{\infty}$ & $\stackrel{0}{0}$ & 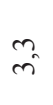 & $\stackrel{0}{i}$ & กิ \\
\hline & & \multicolumn{2}{|c|}{ 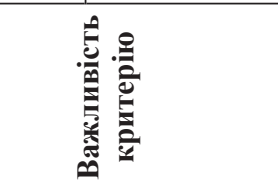 } & กิ & ڤิ & 고 & $\stackrel{m}{n}$ & $\stackrel{m}{n}$ & $\stackrel{8}{ }$ \\
\hline & & \multicolumn{2}{|r|}{ 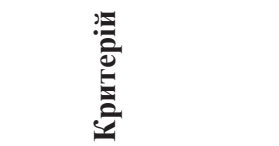 } & $x^{m}$ & $x^{0}$ & 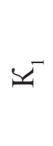 & $s^{+}$ & $x^{n}$ & 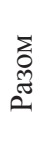 \\
\hline
\end{tabular}


групами. Оцінка кожної підгрупи чинників за обраними критеріями здійснена на основі методу експертних оцінок на основі використання 10-бальної шкали. Результати оцінювання наведено у таблиці 2.

За результатами обчислень визначено, що найбільше значення мають підгрупи технологічних та культурно-етичних чинників. На основі визначення зваженої оцінки значущості чинників обчислено вагомість підгруп чинників макросередовища (табл. 3).

Таблиця 3

Вагомість груп чинників макросередовища

\begin{tabular}{|l|c|}
\hline \multicolumn{1}{|c|}{ Група чинників } & Коефіціснт вагомості \\
\hline Політико-правові & 0,20 \\
\hline Економічні & 0,15 \\
\hline Культурно-етичні & 0,24 \\
\hline Соціально-демографічні & 0,14 \\
\hline Технологічні & 0,27 \\
\hline Разом & 1,0 \\
\hline
\end{tabular}

Джерело: укладено автором

Розраховано інтегральну оцінку чинників макросередовища, яка дорівнює добутку експертної оцінки на коефіцієнт його вагомості. Коефіцієнт вагомості свідчить про ступінь досягнення максимально можливого значення впливу чинників окремої групи (табл. 4).

Таблиця 4

Інтегральна оцінка чинників макросередовища

\begin{tabular}{|l|c|c|c|}
\hline \multicolumn{1}{|c|}{ Група чинників } & Можливості & Загрози & $\begin{array}{c}\text { Інтегральна } \\
\text { оцінка }\end{array}$ \\
\hline Політико-правові & 0,72 & $-1,02$ & $-0,3$ \\
\hline Економічні & 0,3195 & $-0,585$ & $-0,2655$ \\
\hline Культурно-етичні & 2,016 & $-0,24$ & 1,776 \\
\hline Соціально-демографічні & 0,084 & $-0,182$ & $-0,098$ \\
\hline Технологічні & 1,215 & $-0,648$ & 0,567 \\
\hline Загалом & 4,3545 & $-2,675$ & 1,6795 \\
\hline
\end{tabular}

Джерело: укладено автором 
Розподіл чинників свідчить про те, що в цілому чинники макрооточення здійснюють нейтральний вплив на розвиток ринку, що свідчить про необхідність враховувати існуючі тенденцій, однак вони не мають системоутворюючого характеру. Тож наведені чинники здатні перешкоджати розвитку ринку та становити певні загрози, хоча й незначні (рис. 3).

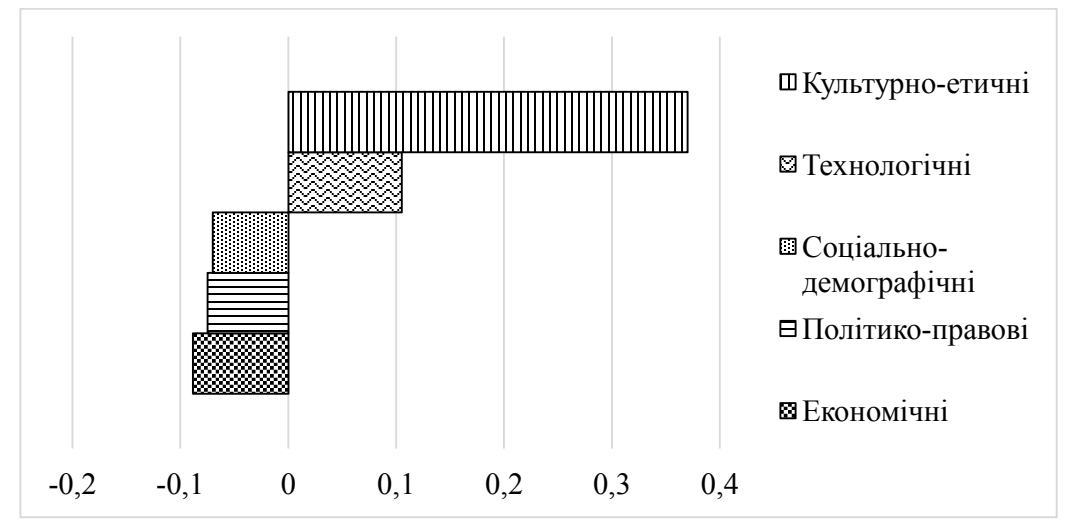

Рис. 3. Коефіціснт впливу чинників макросередовища

Джерело: укладено автором

Так, позитивний вплив на розвиток бізнесу на ринку продуктів та послуг харчування дітей шкільного віку здійснюють культурно-етичні на технологічні чинники. Вони здатні формувати нові можливості для розвитку бізнесу. Тенденції у зміні культурі харчування населення має сприятливий вплив, що вказує на необхідність використання суб'єктами господарювання нових можливостей задля розвитку бізнесу у сегменті. Політико-правові, економічні, соціально-демографічні чинники впливають слабкіше, однак їх вплив має здебільшого негативний характер.

\section{4. Оцінка впливу чинників мікросередовища ринку}

3 метою здійснення аналізу чинників мікрооточення необхідно визначити споживачів, конкурентів, постачальників, посередників, контактні аудиторії тощо. Результати аналізу споживчого статусу дитини дозволяють стверджувати, що споживачем на ринку продуктів та послуг 
харчування дітей шкільного віку виступає дитина віком 6-17 років (з отримання права здійснювати дрібні побутові угоди до досягнення повноліття). Діти на ринку продуктів та послуг харчування замовляють, купують та споживають продукти харчування для особистих потреб.

Організація харчування дітей шкільного віку передбачає певне співвідношення джерел отримання ними їжі протягом навчального дня за місцем проживання та за його межами. Діти шкільного віку як споживачі продуктів та послуг харчування мають такі ж очікування, що й дорослий сегмент ринку, однак, вони здебільшого прагнуть емоційної складової пропозиції: смакового задоволення від споживання продуктів, різноманіття в асортименті, естетики тощо. Одним 3 інструментів маркетингової стратегії закладів громадського харчування $є$ внутрішня організація їх простору. Новосельчук Н.С. у своїх роботах довела необхідність індивідуального підходу до архітектурно-художнього вирішення інтер'єру та застосування сучасних тенденцій в залежності від специфіки закладу. Споживач сприймає роботу закладу харчування через дві основні складові: рівень харчування та культуру обслуговування. Відвідувачам важливо не тільки отримати якісну їжу, а й почувати себе комфортно й невимушено [10, с. 451]. Найчастіше внутрішнє оздоблення та дизайн інтер'єру закладів харчування є демонстрацією цінового сегменту ринку, на який орієнтований даний заклад. Відповідно, заклади харчування при освітніх установах $\epsilon$ бюджетними, які не передбачають наявності маркетингової стратегії та підходів до позиціювання, що прямо відображається на наявності здебільшого застарілих інтер'єрів та традиційних підходів до оздоблення. Тенденції зміни споживчих очікувань дозволяють оцінити їх вплив на діяльність шкільної їдальні (табл. 5).

При аналізі конкурентів необхідно висунути гіпотезу конкурентної стратегії для фірми. 3 цією метою обрано альтернативні джерела отримання продуктів харчування дітьми шкільного віку та здійснено експертну оцінку показників їх діяльності з огляду на безпекові аспекти харчування дітей. За результатами визначено сильні та слабкі сторони шкільної їдальні порівняно з конкурентами.

Відповідно до п. 11 «Порядку організації харчування дітей у навчальних та оздоровчих закладах», затвердженому спільним наказом МОЗ України та МОН України від 01.06.2005 № 242/329 та зареє- 
Таблиця 5

\section{Оцінка чинників мікрооточення шкільної їдальні} категорії «Споживачі»

\begin{tabular}{|c|c|c|c|}
\hline Чинник & Тенденції зміни & $\begin{array}{c}\text { Характер впливу на } \\
\text { підприсмство } \\
\end{array}$ & $\begin{array}{c}\text { Загроза / } \\
\text { можливість }\end{array}$ \\
\hline \multirow{4}{*}{ 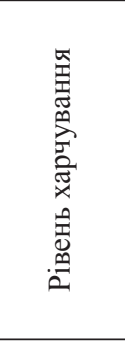 } & $\begin{array}{l}\text { Зростання вимог споживачів } \\
\text { до якості продукції }\end{array}$ & $\begin{array}{l}\text { Неможливість швидко } \\
\text { реагувати на запити } \\
\text { споживачів }\end{array}$ & Загроза \\
\hline & $\begin{array}{l}\text { Зростання вимог споживачів } \\
\text { до асортименту продукції }\end{array}$ & \begin{tabular}{|l} 
Зміни асортименту в \\
межах тендерних умов
\end{tabular} & Можливість \\
\hline & $\begin{array}{l}\text { Обмеженість фінансових } \\
\text { можливостей }\end{array}$ & $\begin{array}{l}\text { Дотримання тендерних } \\
\text { умов }\end{array}$ & Загроза \\
\hline & Прагнуть різноманіття & $\begin{array}{l}\text { Зміни асортименту в } \\
\text { межах тендерних умов } \\
\end{array}$ & Можливість \\
\hline \multirow{3}{*}{ 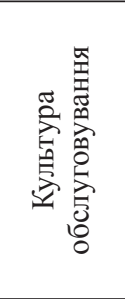 } & $\begin{array}{l}\text { Зростання вимог споживачів } \\
\text { якості обслуговування }\end{array}$ & $\begin{array}{l}\text { Покращення якості } \\
\text { харчового сервісу }\end{array}$ & Можливість \\
\hline & $\begin{array}{l}\text { Зростання вимог споживачів } \\
\text { до естетичності оздоблення } \\
\text { приміщень шкільної їдальні }\end{array}$ & $\begin{array}{l}\text { Модернізація } \\
\text { приміщень }\end{array}$ & Можливість \\
\hline & $\begin{array}{l}\text { Застосування інноваційних } \\
\text { сучасних технологій у } \\
\text { харчовому сервісі }\end{array}$ & \begin{tabular}{|l} 
Впровадження \\
технологічних та \\
сервісних інновацій \\
\end{tabular} & Можливість \\
\hline
\end{tabular}

Джерело: укладено автором

строваному в Міністерстві юстиції України 15.06.2005 за № 661/10941, харчування дітей у навчальних закладах забезпечується безпосередньо у закладі. При відсутності їдальні, харчоблоку дітей харчують у закладі громадського харчування або поставляються готові страви від підприємства громадського харчування. Не мають власних 27 харчоблоків 976 закладів загальної середньої освіти, 171 вищих навчальних закладах I-II рівня акредитації та професійно-технічних навчальних закладів. На даний час забезпечуються лише буфетною продукцією 510 (3,2\%) шкіл та 154 (12\%) ПТНЗ, ССУЗ, ВНЗ І-ІІ ст. акредитації.

У 2017 році забезпечувались лише буфетною продукцією 758 (4,5\%) шкіл та 140 (11,3\%) ПТН3, ССУ3, ВНЗ І-ІІ ст. акредитації. Не мають достатньої кількості холодильного обладнання 295 шкіл. Основна кількість холодильного обладнання експлуатується більше 30 років (особливо низькотемпературне). Технологічного обладнання не виста- 
чає у 711 школах. Термін експлуатації застарілого обладнання становить більше 20 років.

Опубліковані дані щодо санітарно-епідеміологічної ситуації в Україні за 12 місяців 2018 року свідчать про наявність значних проблем у якості роботи операторів ринку послуг харчування дітей. Так, у 2018 р. працівниками територіальних органів Держпродспоживслужби з питань дотримання вимог санітарного законодавства було здійснено перевірку 21786 (у 2017 році - 16300) об’єктів нагляду, у тому числі 773 (у 2017 році - 1310) харчових об'єктів, що склало 0,5\% від їх загальної кількості. Порушення встановлені у 46,5\% випадків (табл. 6).

Таблиця 6

Обсяги комісійних перевірок Держпродпоживслужби у 2017-2018 pp.

\begin{tabular}{|c|c|c|c|}
\hline \multirow[t]{2}{*}{ Об'скти нагляду } & \multicolumn{2}{|c|}{$\begin{array}{c}\text { Кількість перевірених } \\
\text { об'єктів }\end{array}$} & \multirow{2}{*}{$\begin{array}{c}\text { Встановленс } \\
\text { порушень } \\
\text { у } 2018 \text { р.,\% }\end{array}$} \\
\hline & 2017 p. & 2018 p. & \\
\hline $\begin{array}{l}\text { Об’єкти централізованого } \\
\text { постачання }\end{array}$ & 783 & 1337 & 55,4 \\
\hline Оздоровчі заклади для дорослих & 327 & 394 & 33,5 \\
\hline $\begin{array}{l}\text { Лікувально-профілактичні } \\
\text { заклади }\end{array}$ & 280 & 205 & 28,2 \\
\hline Харчові об'єкти & 10398 & 3003 & 46,5 \\
\hline $\begin{array}{l}\text { Підприємства сільського } \\
\text { господарства }\end{array}$ & 85 & 109 & 49,5 \\
\hline Промислові підприємства & 89 & 84 & 19 \\
\hline $\begin{array}{l}\text { Об'єкти поводження з твердими } \\
\text { побутовими відходами }\end{array}$ & 328 & 518 & 67,2 \\
\hline Сміттєзвалища & 374 & 663 & 67,6 \\
\hline Інші об’єкти & 4505 & 3807 & 47,3 \\
\hline
\end{tabular}

Джерело: укладено автором на основі даних иkrstat.gov.иа

За результатами здійснених у 2018 році заходів державного нагляду (контролю) на підставі встановлених порушень санітарного законодавства накладено 280 штрафів. Переважну кількість штрафів - 171 (61\%) накладено за встановленні порушення в дошкільних та загальноос- 
вітніх навчальних закладах. Проведено 19,2 тис. обстежень закладів загальної середньої освіти, за результатами яких встановлено порушення вимог в 42\% випадків (8,2 тис), 11,4 тис. обстежень закладів оздоровлення/відпочинку, під час яких встановлено порушення в $25 \%$ закладів (2,9 тис). Значна кількість порушень стосується незадовільної матеріально-технічної бази. Існує негативна тенденція щодо забезпечення закладів для дітей питною водою гарантованої якості. У зв'язку 3 відсутністю джерел централізованого чи локального водопостачання у населених пунктах або невідповідністю води з локальних джерел нормативам залишаються навчальні заклади, які ще працюють на привозній воді. Так, 370 (3,0\%) закладів дошкільної освіти, 504 (3,0\%) закладів загальної середньої освіти та 3 (0,2\%) ПТНЗ, ССУЗ, ВНЗ І-ІІ ст. акредитації працюють на привозній воді.

На деяких адміністративних територіях є проблемним питання виконання норм харчування відповідно до постанови Кабінету Міністрів України від 22.11.2004 №1591 «Про затвердження норм харчування у навчальних і оздоровчих закладах». Невиконання норм харчування та недотримання вимог санітарногігієнічного та протиепідемічного режимів підтверджено лабораторними дослідженнями. Питома вага проб з відхиленням по калорійності становила 6,7\% (2017 - 6,0\%), показник відхилень бактеріального забруднення страв становив 3,8\% (2017 - 4,2\%), відхилення змивів за умовно патогенною 28 мікрофлору з обладнання, інвентарю, рук та санітарного одягу кухарів закладів - 4,9\% (2017 - 4,2\%). Раптово обстежено на бактеріоносійство 4271 особу персоналу закладів освіти, наявність носійства збудників інфекційних хвороб серед персоналу харчоблоків встановлено у 145 осіб $(3,4 \%)$.

Основними порушеннями під час обстежень були недотримання вимог щодо транспортування харчових продуктів та продовольчої сировини, порушення термінів проведення обов'язкових медичних оглядів обслуговуючим персоналом, недотримання термінів реалізації харчових продуктів, порушення товарного сусідства та температурних умов, як при транспортуванні, так і при зберіганні харчових продуктів та продовольчої сировини, несвоєчасне ведення медичної документації по контролю за організацією харчування, порушення правил відбору та зберігання добових проб, порушення технології приготування 
страв, що підтверджено результатами лабораторних досліджень, відсутність або недотримання погоджених територіальними органами Держпродспоживслужби перспективних двотижневих меню, порушення правил особистої гігієни персоналом, порушення санітарно-гігієнічного та протиепідемічного режимів на харчоблоках та харчових об'єктів, які виробляють, реалізують та постачають харчові продукти, що підтверджено результатами лабораторних досліджень, вживання продуктів, заборонених для використання у навчальних закладах.

Порушення вимог санітарногігієнічного та протиепідемічного режимів призводять до спахалів гострих кишкових інфекцій.

3 метою визначення вагомості підгруп чинників мікрооточення, оцінка кожної підгрупи за обраними критеріями здійснена на основі методу експертних оцінок на основі використання 10-бальної шкали. За результатами обчислень визначено, що найбільше значення мають підгрупи споживачів та конкурентів. На основі визначення зваженої оцінки значущості чинників обчислено вагомість підгруп чинників мікросередовища (табл. 7).

Таблиця 7

Вагомість груп чинників мікрооточення

\begin{tabular}{|l|c|}
\hline \multicolumn{1}{|c|}{ Група чинників } & Коефіціснт вагомості \\
\hline Споживачі & 0,42 \\
\hline Конкуренти & 0,28 \\
\hline Постачальники & 0,17 \\
\hline Контактні аудиторії & 0,12 \\
\hline Разом & 1,0 \\
\hline
\end{tabular}

Розраховано інтегральну оцінку чинників мікросередовища, яка дорівнює добутку експертної оцінки на коефіцієнт його вагомості. Отримані дані зведені у підсумковій таблиці чинників ринкових загроз та можливостей (додаток). Коефіцієнт впливу групи чинників розраховуємо як відношення інтегральної оцінки групи чинників до добутку максимально можливої оцінки (2) та кількості чинників у групі (табл. 7).

Розподіл чинників згідно наведеної шкали свідчить про те, що чинники мікрооточення створюють в цілому нейтральне оточення для розвитку ринку (рис. 4). 
Таблиця 7

Характер впливу мікрооточення

\begin{tabular}{|c|c|c|c|c|c|}
\hline Група чинників & 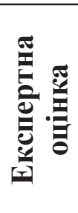 & 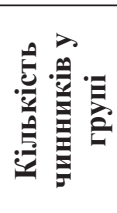 & 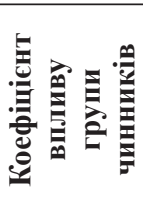 & 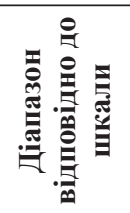 & 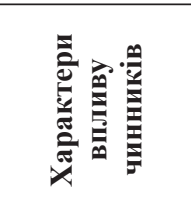 \\
\hline Споживачі & 7 & 6 & 0,5833 & $0,5-1,0$ & Позитивний \\
\hline Постачальники & -4 & 6 & $-0,1333$ & $-0,25-0$ & Негативний \\
\hline Контактні аудиторії & 2,1 & 3 & 0,1750 & $0-0,25$ & Нейтральний \\
\hline Конкуренти & 1,4 & 15 & 0,2333 & $0-0,25$ & Нейтральний \\
\hline Загалом & 6,5 & 30 & 0,1083 & $0-0,25$ & Нейтральний \\
\hline
\end{tabular}

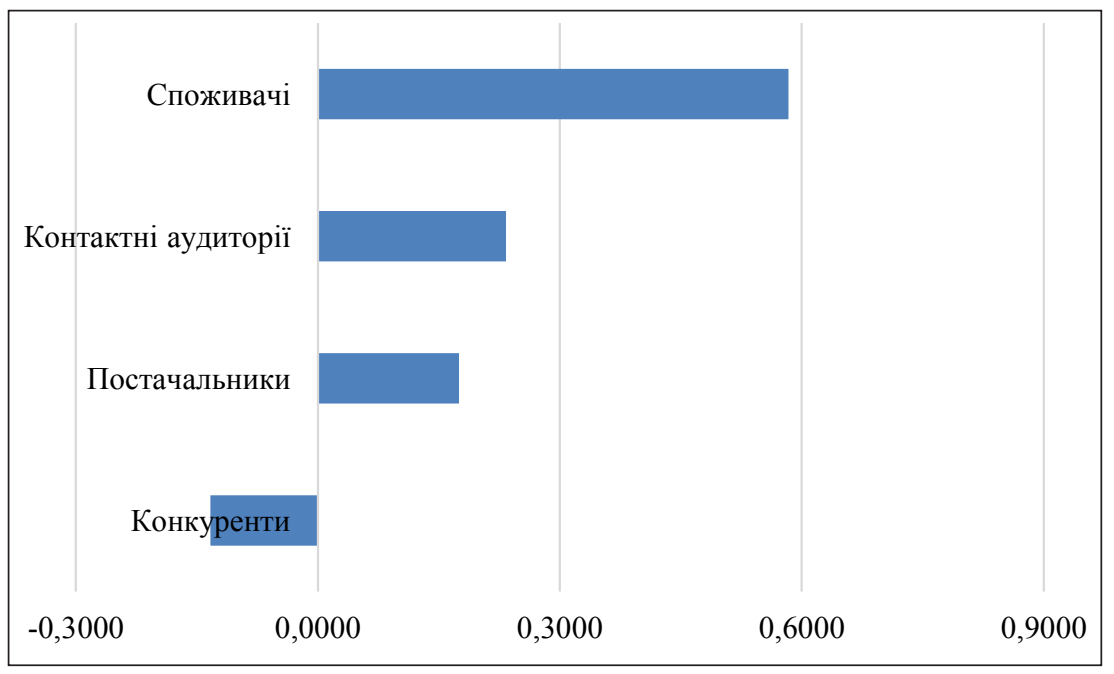

Рис. 4. Коефіцієнт впливу чинників мікросередовища

Джерело: укладено автором

Позитивні можливості для суб'єктів господарювання формують споживачі. Вплив постачальників має негативний характер. 


\section{5. Оцінка альтернативних варіантів рішення проблеми}

За результатами аналізу чинників макросередовища та мікрооточення узагальнено існуючі альтернативи розвитку діяльності підприємств на ринку продуктів та послуг харчування для дітей та розглянуто їх сильні й слабкі сторони (додаток). За зазначеними варіантами визначено їх здатність подолати існуючі загрози та використати можливості, які формують чинники макро- та мікрооточення. 3 метою вибору найбільш ефективних альтернативних напрямів для реалізації здійснено АВС-аналіз альтернатив (табл. 8).

Обрано діапазон:

- Категорія А - 0-80\%;

- Категорія В - 80-95\%;

- Категорія С - 95-100\%.

Таблиця 8

Оцінка потенціалу альтернативних варіантів рішення

\begin{tabular}{|c|c|c|c|c|}
\hline Альтернатива & Зрушення & Частка & $\begin{array}{c}\text { Накопичувальний } \\
\text { підсумок }\end{array}$ & Категорія \\
\hline 7 & 3,568 & 19,21 & 19,21 & $\mathrm{~A}$ \\
\hline 3 & 3,25 & 17,50 & 36,71 & $\mathrm{~A}$ \\
\hline 9 & 2,463 & 13,26 & 49,98 & $\mathrm{~A}$ \\
\hline 4 & 2,125 & 11,44 & 61,42 & $\mathrm{~A}$ \\
\hline 5 & 1,35 & 7,27 & 68,69 & $\mathrm{~A}$ \\
\hline 2 & 1,228 & 6,61 & 75,30 & $\mathrm{~A}$ \\
\hline 10 & 1,005 & 5,41 & 80,71 & $\mathrm{~A}$ \\
\hline 13 & 0,98 & 5,28 & 85,99 & $\mathrm{~B}$ \\
\hline 8 & 0,906 & 4,88 & 90,87 & $\mathrm{~B}$ \\
\hline 12 & 0,588 & 3,17 & 94,04 & $\mathrm{~B}$ \\
\hline 1 & 0,444 & 2,39 & 96,43 & $\mathrm{~B}$ \\
\hline 6 & 0,3995 & 2,15 & 98,58 & $\mathrm{C}$ \\
\hline 14 & 0,156 & 0,84 & 99,42 & $\mathrm{C}$ \\
\hline 15 & 0,06 & 0,32 & 99,74 & $\mathrm{C}$ \\
\hline 11 & 0,048 & 0,26 & 100,00 & $\mathrm{C}$ \\
\hline Загалом & 18,5705 & 100 & & \\
\hline
\end{tabular}

Джерело: укладено автором 
Таким чином, найбільш ефективно подолати існуючі загрози та використати існуючі можливості дозволяють наступні альтернативні варіанти:

1. Альтернатива № 7. Розвиток маркетингової активності із забезпечення харчуванням учнів закладів середньої освіти з метою створення пропозиції отримання гарячого харчування ними за місцем навчання протягом усього дня. Вивчення уподобань та індивідуальних потреб споживачів та впровадження заходів щодо підвищення рівня їх задоволеності у відповідності до індивідуальних потреб та очікувань.

2. Альтернатива № 3. Дотримання вимог чинного законодавства (норм, інструкцій, стандартів тощо).

3. Альтернатива № 9. Розробка програми модернізації харчового сервісу у шкільних їдальнях шляхом впровадження інформаційних, технологічних, маркетингових та організаційних інновацій; нових форматів харчового сервісу; інновацій, що надають споживачу відчуття додаткових зручностей; інноваційних підходів до обслуговування споживачів.

4. Альтернатива № 4. Впровадження стандартів безпеки та системи контролю якості на всіх стадіях виробництва, у тому числі здійснення вхідного контролю сировини.

5. Альтернатива № 5. Модернізація та оновлення матеріально-технічної, виробничо-технологічної бази, внутрішнього оздоблення шкільної їдальні, модернізація інтер'єру та екстер'єру. Підвищення екологічності та ресурсоощадності виробництва, у тому числі упаковки продукції.

6. Альтернатива № 2. Модернізація товарної пропозиції. Оновлення асортименту, впровадження нових рецептур та технологій приготування страв.

7.Альтернатива № 10. Враховувати рівень платоспроможності населення при формуванні цінової політики, створення можливості формування різних продуктових пропозицій у ціновому діапазоні, подолання відчуття диференціації дітей за рівнем платоспроможності.

\section{6. Висновки}

Результати проведеного дослідження дозволили зазначити, що серед чинників зовнішнього оточення найбільш значний вплив здій- 
снюють чинники культурно-технологічної та технологічної сфери, а серед чинників мікрооточення найзначніше на стан ринку впливають споживачі та конкуренти. До напрямів вирішення існуючих проблем та використання потенційних можливостей, які надає зовнішнє оточення обрано альтернативний набір варіантів. Подальші наукові дослідження передбачають розробку концептуальних основ впровадження найефективніших стратегічних альтернатив на основі маркетингового механізму управління безпекою харчування дітей шкільного віку.

\section{Список літератури:}

1. Буц М.А. Формування культури здорового харчування школярів. Молодий вчений. 2017. № 9.1 (49.1). С. 13-16.

2. Шкуро В.В. Гігієнічна оцінка особливостей харчування молодших школярів у загальноосвітніх навчальних закладах різного типу : автореф. дис. на здобуття наук. ступеня канд. мед. наук : спец. 14.02.01 «Гігієна та професійна патологія». Київ, 2010. 20 с.

3. Луцій О.П., Васюткіна Н.В. Маркетингові дослідження ринку продуктів харчування: організаційно-методичний аспект діяльності суб'єктів господарювання. Європейський ун-т. Київ : Видавництво Європейського ун-ту, 2015. 224 с.

4. Берницька Д. Стратегічний аналіз зовнішнього середовища підприємства методом PEST/STEP аналізу. Економічний аналіз. 2012. № 11 (частина 2). C. 41-45.

5. Старостіна А.О. Маркетингові дослідження. Практичний аспект : навч. посібник. Київ : «Вільямс», 2000. 262 с.

6. Коноваленко А.С. Політико-правові чинники розвитку ринку продуктів харчування для дітей шкільного віку. Вісник Одеського нащіонального університету: науковий журнал. Серія : Економіка. 2019. Т. 24, вип. 4(77). С. 63-68.

7. Konovalenko, A. S. (2019), "Economic factors of food market development for school-age children", Economies' Horizons. no. 3(10), pp. 31-42.

8. Коноваленко А.С. Технологічні чинники розвитку ринку продуктів харчування для дітей. Агросвіт. 2020. Вип. 3. С. 65-72. URL: http://www.agrosvit.info/ $?$ op $=1 \& \mathrm{z}=3086 \& \mathrm{i}=8$

9. Саати Т. Принятие решений. Метод анализа иерархий. Москва : Радио и связь, 1993.

10. Новосельчук Н.Є. Напрями архітектурно-художнього вирішення інтер'єрів закладів громадського харчування. Архітектурний вісник КНУБА. 2017. Вип. 11-12. С. 448-453.

\section{References:}

1. Buts M.A. (2017). Formuvannia kultury zdorovoho kharchuvannia shkoliariv [Formation of a culture of healthy nutrition of students]. Molodyi vchenyi. № 9.1 (49.1), pp. 13-16 
2. Shkuro V.V. (2010). "Hihiienichna otsinka osoblyvostei kharchuvannia molodshykh shkoliariv u zahalnoosvitnikh navchalnykh zakladakh riznoho typu": avtoref. dys. na zdobuttia nauk. stupenia kand. med. nauk: spets. 14.02.01 „Hihiiena ta profesiina patolohiia». Kyiv.

3. Lutsii O.P. and Vasiutkina N.V. (2015). Marketynhovi doslidzhennia rynku produktiv kharchuvannia: orhanizatsiino-metodychnyi aspekt diialnosti subiektiv hospodariuvannia. Kyiv: Vydavnytstvo Yevropeiskoho un-tu.

4. Bernytska D. (2012). Stratehichnyi analiz zovnishnoho seredovyshcha pidpryiemstva metodom PEST/STEP analizu. Ekonomichnyi analiz. Vol. 11, issue 2, pp. 41-45.

5. Starostina A.O. (2000). Marketynhovi doslidzhennia. Praktychnyi aspekt. [Marketing researches. Practical aspect]. Kyiv: Viliiams, p. 262.

6. Konovalenko A.S. (2019). Polityko-pravovi chynnyky rozvytku rynku produktiv kharchuvannia dlia ditei shkilnoho viku. Visnyk Odeskoho natsionalnoho universytetu: naukovyi zhurnal. Seriia: Ekonomika, vol. 24, issue 4(77), pp. 63-68.

7. Konovalenko, A.S. (2019), "Economic factors of food market development for school-age children", Economies' Horizons. no. 3(10), pp. 31-42.

8. Konovalenko A.S. (2020). Technologichni chynnyky rozvytku rynku produktiv kharchuvannia dlia ditei shkilnoho viku. Agroworld, vol. 3, pp. 65-72. URL: http://www.agrosvit.info/?op $=1 \& \mathrm{z}=3086 \& \mathrm{i}=8$

9. Saati T. (1993). Prinyatie resheniy. Metod analiza ierarhiy. Moscow: Radio i svyaz.

10. Novoselchuk N.Ie. (2017), "Areas of architectural and artistic solution of the interiors of catering establishments". Arkhitekturnyi visnyk KNUBA, vol. 11-12, pp. $448-453$. 